\title{
THE CONTRIBUTION OF UNIVERSITY INPUT SCORES THROUGH JOINT SELECTION FOR STATE UNIVERSITIES ADMISSION (SBMPTN) TOWARDS THE STUDENTS' LEARNING OUTCOMES
}

\author{
Sulthoni \\ Faculty of Education, State University of Malang, Indonesia \\ sulthoni.fip@um.ac.id
}

\begin{abstract}
The aim of this research is to examine the distribution of the university input scores through SBMPTN towards the students' learning outcomes. This research used quantitative approach with correlational descriptive design. The research population of this study were the university students from the class of 2014/2015 and 2015/2016. The sample was 600 students considering the department or major in Universitas Negeri Malang (UM) dan Universitas Negeri Surabaya, using random sampling technique. The data was collected using documentation technique, while the data analysis used test analysis. The result of the study showed that the university input scores through SBMPTN have the high contribution towards the students' learning outcomes.
\end{abstract}

Keywords: university input score, students' learning outcomes

\section{INTRODUCTION}

Equity and improvement of the educational quality are two important aspect that become the main priority in the development of educations in university. To generate the qualified graduates, one of the requirements is the enhancement of the education and learning process. To improve the educational equity, the other requirement is the improvement of the graduates quantity. Those two aspects are the basic of the policy development in the university. Educational quality is not only determined by the process or the result of the learning, but also by the quality of the input. The input variable is one of the most influential factors towards the educational quality [1].

If the input is superior, the graduates would be qualified. Evaluation of learnings is the evaluation applied in the learning field. In other words, evaluation of learnings is a reviewing process or aspects assessment in the learning activities, whether in the context, input, process, or the result of learnings. This is in line with the statement from Groundlund and Linn [2] which states that the evaluation of learning is a process of collecting, analyzing, and interpreting an information systematically to set the learning objectives are achieved. The main target of the evaluation of learning is the information that can be used as the basic consideration to make a decision in the learning activities.

\section{A. Research Design}

\section{METHODS}

The approach used in this research is quantitative approach. Based on the design, especially from the data analysis, this research used descriptive correlational design. Therefore, the research design used descriptive correlational design.

\section{B. B. Population and Sample of the Research}

The population of this research were the students of the first and second semester (class of 2014/2015 and 2015/20116). By considering the proportion and the characteristic of the population, sampling was conducted. The determination of the amount of the sample was based on the characteristics of the population and the formula of sampling test instrument. The trial subjects, considering the minimum amount, was 600 students from two locations, they were State University of Malang and State University of Surabaya. The sampling technique used in this research is random sampling.

\section{Data Collection Technique}

To collect the desired data, this research used one technique, which was documentation. This technique was used to collect the data of score from the admission test and academic achievements of semester 1 and 2 students.

\section{Data Analysis Technique}

In accordance with the purpose of the study, the research used t test to analyze the data using SPSS program.

\section{RESULTS}

The input score of university through SBMPTN related to the students' learning outcomes shows that $t$ value $1.204>$ t table 229 . This shows that there is a significant correlation between input score through SBMPTN and the students' learning outcomes. In conclusion, the input score of university through SBMPTN has a high contribution towards the students' learning outcomes.

\section{DISCUSSION}

Evaluation activity includes measurement and assessment. Evaluation is a process of determining the value based on some certain standards. Those standards contain qualitative meanings, such as good-bad, highlow, meet the criteria-not meet the criteria, etc. The result of the measurement is the basic of evaluation process. Therefore, there is an obvious correlation between measurement and evaluation.

There are some kinds of evaluation. In terms of its purpose, there are five types of evaluation: (1) selective, (2) diagnostic, (3) placement, (4) formative, and (4) summative. Selective Evaluation is an evaluation which purpose is to select the input. If it is applied in the college, it is observable in the admission 
of new students. Through this evaluation, the university can get the qualified input. In this case, they are the students with good skills. The result showed that there is a correlation between the input score of SBMPTN and the students' learning outcomes.

To acquire the actual predictive validity, there has to be a verification of reliability test and selection ratio. Using the assumption that the distributions of the predictor score and the criteria score are normal bivariate, Taylor and Russel developed a technique to evaluate the effectiveness of a selection test or evaluation of selection. Related to this accuracy of prediction, technically it involves six points, i.e. (1) success criteria, (2) treatment strategy, (3) applicant source, (4) kinds and number of predictors, (5) how to combine predictors, and (6) how to determine the passing grade [4].

Success criteria is related to the performance after accepted of also known as later performance, whether the performance during college or after graduate. To select the new students well, there has to be a clearly defined sucess criteria. The criteria of later performance during the study can involve the learning achievement, learning period, scientific attitude, responsibility, social awareness, etc. The criteria of later performance for college graduate involves the quickness in getting a job, professionality, appreciation of the work, the contribution towards society, etc. Those criteria are the basic of measuring the prediction accuracy of student admission.

Treatment strategy involves how the the learning process is held in the college or univesity. Theoretically, there are two treatment strategies: fixed treatment strategy and adaptive treatment strategy [4]. In the fixed treatment strategy, the college uses the fixed methods and not modified according to the students' characteristics during the learning process such as the use of package system. In adaptive treatment stretegy, although the programs are already set, it still can be modified according to the students' characteristics, such as in the course credit system which allows the students to choose. Thus, the inadequacy of the selection is easily examined in the adaptif strategy system.

Sources of applicants are related to the amount and quality of the applicants. There are two strategies that can be applied. First, the university is able to set the minimum academic requirements for the applicants. Second, detecting the applicants through the selection ratio that is a ratio between the quota and the number of applicants. The smaller the selection ratio, the higher the quiality of the applicants because the university can select from a large number with more heterogenous competence and possibly qualified applicants.

There are various results from previous studies using those techniques. The result from Garret, Pasanella, or Lavin show that there is a positive correlation between intelligence predictors and the students' grade point [3]. In some other studies, the use of ACTPC (American College Testing Program Composite), CEBSAT (College Entrance Examination Board Scholastic Aptitute Test), DAT (Differential
Aptitude Tests) also showed a positive correlation with the students' learning achievements [5].

\section{REFERENCES}

[1] Haller, E. J., \& Strike, K. A. 1986. An Introduction to Educational Administration. New York: Longman, Inc.

[2] Gronlund, N. E., and Linn, R. L. 1990. Mesurement and Evaluation in Teaching. New York: Macmillan Publishing Company.

[3] Suryabrata, S. 2000. Pengembangan Alat Ukur Psikhologis. Yogyakarta: Penerbit Andi.

[4] Suryabrata, S. 2004. Pengembangan Sistem Seleksi Calon Mahasiswa Perguruan Tinggi yang Akurat dan Berkeadilan. Paper of National Seminar on Himpunan Evaluasi Pendidikan Indonesia, Yogyakarta.

[5] Nitko, A. J. 1983. Educational Test and Measurement: An Introduction. New York: Harcourt Brace Jovanovich, Inc. 